\title{
Serum and Salivary Immunoglobulins levels in Tobacco Smokers of Baghdad Governorate
}

\author{
Shatha F. Tariq ${ }^{1}$, Raghad N. Shihab ${ }^{1}$ \\ ${ }^{1}$ Assist. Lec. Department of Medical lab. Techniques, Dijlah University college /Iraq
}

\begin{abstract}
It was shown that tobacco smoking was a major environmental factor which altered numerous changes in both antibody and cell mediated immune responses leading to increase the capability of the individual to develop various inflammatory and autoimmune diseases, thus the current study aimed to assess the levels of both serum and salivary Igs in 35 individuals who smoking tobacco and compared them to 35 non-smokers group. Results of this study revealed a slightly but non-significant increased $(p<0.05)$ in the serum and salivary levels of IgM in smokers as compared to non-smokers, while the serum and salivary levels of both $\operatorname{IgG}$ and $\operatorname{IgA}$ shown a significantly decreased $(\mathrm{p} \leq 0.05)$ in smokers as compared to non-smokers group. No positive correlation was found in the serum and salivary Igs levels in smokers. Body mass index (BMI) and smoking index (SI) were calculated for the smokers group, however, no significant differences were found in both serum and salivary Igs levels.
\end{abstract}

Keywords: Health, Smoking, Immunoglobulins (IgM, $\operatorname{Ig} G$ and $\operatorname{Ig} A)$; toxicity

\section{Introduction}

Tobacco smoking is one of the worldwide epidemic habits that associated with human beings death and morbidity ${ }^{(1)}$.Various chronic diseases in the brain, respiratory tract and cardiovascular system are induced because of the antigenic, carcinogenic and mutagenic impacts of the toxic chemical compounds which found in tobacco ${ }^{(2)}$. The World Health Organization (WHO) expected that in 2030 tobacco smoking will be one of the main causes that lead to the death of about 8 million individuals especially in the developing countries ${ }^{(3)}$. According to Hussain and Sullivan study in Iraq, about $29-31 \%$ males and $3-4 \%$ females considered as active smokers ${ }^{(4)}$. Inhalation of tobacco smoking has many adverse effects on both humeral and cellular immune response, it implicated in the inhibition or the production of many pro-inflammatory and antiinflammatory cytokines in human body ${ }^{(5)}$. Many studies confirmed that tobacco smoking has prospective effects on inflammation process and autoimmunity such as Chronic Obstructive Pulmonary Disease (COPD), Rheumatoid Arthritis (RA) and Systemic Lupus Erythematosus $(\mathrm{SLE})^{(6)}$.Immunoglobulins (Igs) are glycoproteins found in serum, tissues and body fluids, synthesized by plasma cells in response to antigenic stimulation ${ }^{(7)}$. Five classes of Igs have been established which include: IgM: plays an important role in primary immune response, IgG: considers as the main Ig in secondary immune response, IgA: protects the mucosal surfaces from infections, IgE: acts as anti-parasitic and anti-allergenic, IgD: acts as B-cell receptor ${ }^{(8,9)}$. Igs that present in saliva play a very important role in oral cavity protection especially salivary IgA which inhibit the entry of infectious microorganisms ${ }^{(10)}$. The current study aimed to investigate whether there are differences in the serum and salivary Igs levels in tobacco smokers and non-smokers.

\section{Materials and Method}

The present study was carried out on 70 healthy males (with no clinical signs) lived in Bagdad Governorate, 35 individuals were smokers and 35 individuals were non-smokers, their age range from (18-40) years. Body mass index (BMI) was calculated by dividing the body weight $(\mathrm{kg})$ on the square of the body height $\left(\mathrm{m}^{2}\right)$ in both smokers and non-smokers as the followings:7 smokers and 8 non-smokers had underweight BMI $<18.5 \mathrm{~kg} / \mathrm{m}^{2}$, 20 smokers and 22 non-smokers had normal BMI (18.524.9) $\mathrm{kg} / \mathrm{m}^{2}, 5$ smokers and 4 non-smokers had over weight BMI (25- 29.9) kg/m², while only 3 smokers 
and 1 non-smokers had obese BMI $>30 \mathrm{~kg} / \mathrm{m}^{2}$. Smoking index (SI) for smokers was calculated as the number of cigarettes per day multiplying by the years of smoking as the followings: 30 smokers had mild SI $<200$ while only 5 smokers had moderate SI (200-600). Serum samples from both smokers and non-smokers were obtained after centrifugation of blood samples for $5 \mathrm{~min}$. at $3000 \mathrm{rpm}$, then they were stored at $-20 \mathrm{C}^{\circ}$ until use. Unstimulated saliva samples were collected from the study subjects (whom prevented from eating and drinking for nearly $1 \mathrm{hr}$. prior to donation) after cleaning and rinsing their oral cavity. All saliva samples were centrifuged for 10 min. at $10000 \mathrm{rpm}$, then the supernatants were stored at $-20^{\circ} \mathrm{C}$ until use. The levels of serum and salivary Igs were measured by using the turbidimetric immunoassay. In order to analyze the data of the current study which were presented as mean \pm Standard Error (S.E.), SPSS version 25.0 was used, one way ANOVA test has been dependent to find the differences between means which considered significant when the probability $(\mathrm{P})$ value was $\leq 0.05^{(11)}$.

\section{Results}

Serum Levels of Igs (IgM, IgG and IgA) in Smokers and Non-Smokers:

Results of the current study revealed that serum level of IgM showed non-significant increase $(p>0.05)$ in smokers as compared to non-smokers, while the serum levels of both IgG and IgA were decreased significantly $(\mathrm{p} \leq 0.05)$ in smokers as compared to nonsmokers (Table.1).

Table.1: Mean Serum Levels of Igs (IgM, IgG and IgA) in the Study Samples.

\begin{tabular}{|l|l|l|l|l|}
\hline Samples & No. & $\begin{array}{l}\text { Mean } \pm \text { S.E. } \\
\text { IgM(mg/d) }\end{array}$ & $\begin{array}{l}\text { Mean } \pm \text { S.E. } \\
\text { IgG(mg/dl) }\end{array}$ & $\begin{array}{l}\text { Mean } \pm \text { S.E. } \\
\text { IgA(mg/dl) }\end{array}$ \\
\hline Smokers & 35 & $123.188 \pm 5.88 \mathrm{a}$ & $1075.76 \pm 33.112 \mathrm{a}$ & $243.654 \pm 11.774 \mathrm{a}$ \\
\hline Non-Smokers & 35 & $119.385 \pm 2.99 \mathrm{a}$ & $1235.58 \pm 41.014 \mathrm{~b}$ & $197.048 \pm 6.993 \mathrm{~b}$ \\
\hline $\begin{array}{l}\text { *Similar letters=No significant difference }(\mathrm{P}>0.05) \text { between means. } \\
\text { *Different letters=Significant difference }(\mathrm{P} \leq 0.05) \text { between means. }\end{array}$
\end{tabular}

Salivary Levels of Igs (IgM, IgG and $\operatorname{IgA})$ in the Study Samples.

According to the levels of Igs in saliva samples, salivary IgM in smokers showed slightly but non-significant increase ( $p>0.05$ ) as compared to non-smokers; however the levels of salivary IgG and IgA in smokers were decreased significantly $(\mathrm{p} \leq 0.05)$ as compared to non-smokers (Table.2).

Table.2: Mean Salivary Levels of Igs (IgM, IgG and IgA) in the Study Samples.

\begin{tabular}{|l|l|l|l|l|}
\hline Samples & No. & $\begin{array}{l}\text { Mean } \pm \text { S.E. } \\
\text { IgM(mg/dl) }\end{array}$ & $\begin{array}{l}\text { Mean } \pm \text { S.E. } \\
\text { IgG(mg/dl) }\end{array}$ & $\begin{array}{l}\text { Mean } \pm \text { S.E. } \\
\text { IgA(mg/dl) }\end{array}$ \\
\hline Smokers & 35 & $0.585 \pm 0.01 \mathrm{a}$ & $1.869 \pm 0.06 \mathrm{a}$ & $7.365 \pm 0.99 \mathrm{a}$ \\
\hline Non-Smokers & 35 & $0.56 \pm 0.07 \mathrm{a}$ & $4.519 \pm 0.13 \mathrm{~b}$ & $16.05 \pm 0.56 \mathrm{~b}$ \\
\hline $\begin{array}{l}* \text { Similar letters=No significant difference }(\mathrm{P}>0.05) \text { between means. } \\
\text { *Different letters=Significant difference }(\mathrm{P} \leq 0.05) \text { between means. }\end{array}$ & \\
\hline
\end{tabular}


Correlation between Serum Igs (IgM, IgG and IgA) in the Study Samples.

In smokers, negative correlation was found between serum IgM and IgG levels, no correlation was found between serum IgM and IgA levels as well as between serum IgG and IgA levels. In addition, no correlation was found among serum Igs in non-smokers (Table.3).

Table.3: Correlation between Serum Igs levels (IgM, IgG and IgA) in the Study Samples.

\begin{tabular}{|c|c|c|c|c|}
\hline \multicolumn{2}{|c|}{ Serum Igs levels in Smokers } & \multirow{2}{*}{$\begin{array}{l}\mathbf{r} \\
-0.01\end{array}$} & \multirow{2}{*}{\begin{tabular}{|l|}
$\mathbf{p}$ \\
0.956
\end{tabular}} & \multirow{2}{*}{\begin{tabular}{|l} 
Significance \\
Non-significan
\end{tabular}} \\
\hline & $\operatorname{IgG}(\mathrm{mg} / \mathrm{dl})$ & & & \\
\hline & $\operatorname{IgA}(\mathrm{mg} / \mathrm{dl})$ & 0.103 & 0.557 & Non-significant \\
\hline \multirow{2}{*}{$\operatorname{IgG}(\mathrm{mg} / \mathrm{dl})$} & $\operatorname{IgM}(\mathrm{mg} / \mathrm{dl})$ & -0.01 & 0.956 & Non-significant \\
\hline & $\operatorname{IgA}(\mathrm{mg} / \mathrm{dl})$ & 0.03 & 0.864 & Non-significant \\
\hline \multirow{2}{*}{$\operatorname{IgA}(\mathrm{mg} / \mathrm{dl})$} & $\operatorname{IgM}(\mathrm{mg} / \mathrm{dl})$ & 0.103 & 0.557 & Non-significant \\
\hline & $\operatorname{IgG}(\mathrm{mg} / \mathrm{dl})$ & 0.03 & 0.864 & Non-significant \\
\hline \multicolumn{2}{|c|}{ Serum Igs levels in Non-Smokers } & $\mathrm{r}$ & $\mathrm{p}$ & Significance \\
\hline \multirow{2}{*}{$\operatorname{IgM}(\mathrm{mg} / \mathrm{dl})$} & $\operatorname{IgG}(\mathrm{mg} / \mathrm{dl})$ & 0.299 & 0.081 & Non-significant \\
\hline & $\operatorname{IgA}(\mathrm{mg} / \mathrm{dl})$ & 0.387 & 0.092 & Non-significant \\
\hline \multirow{2}{*}{$\operatorname{IgG}(\mathrm{mg} / \mathrm{dl})$} & $\operatorname{IgM}(\mathrm{mg} / \mathrm{dl})$ & 0.299 & 0.081 & Non-significant \\
\hline & $\operatorname{IgA}(\mathrm{mg} / \mathrm{dl})$ & 0.163 & 0.35 & Non-significant \\
\hline \multirow{2}{*}{$\operatorname{IgA}(\mathrm{mg} / \mathrm{dl})$} & $\operatorname{IgM}(\mathrm{mg} / \mathrm{dl})$ & 0.387 & 0.092 & Non-significant \\
\hline & $\operatorname{IgG}(\mathrm{mg} / \mathrm{dl})$ & 0.163 & 0.35 & Non-significant \\
\hline
\end{tabular}

Correlation between Salivary Igs (IgM, IgG and IgA) in the Study Samples.

In smokers, negative correlation was found between salivary IgM and IgG levels as well as between salivary IgM and IgA levels; however no correlation was found between salivary IgG and IgA levels. In addition, in nonsmokers negative correlation was found between salivary IgM and IgA levels but no correlation was found between salivary IgM and IgG levels as well as between salivary IgG and IgA levels (Table.4).

Table.4: Correlation between Salivary Igs levels (IgM, IgG and IgA) in the Study Samples.

\begin{tabular}{|c|c|c|c|c|}
\hline \multicolumn{2}{|c|}{ Salivary Igs levels in Smokers } & \multirow{2}{*}{$\begin{array}{l}\mathbf{r} \\
-0.092\end{array}$} & \multirow{2}{*}{\begin{tabular}{|l|}
$\mathbf{p}$ \\
0.599
\end{tabular}} & \multirow{2}{*}{\begin{tabular}{|l} 
Significance \\
Non-significant
\end{tabular}} \\
\hline & $\operatorname{IgG}(\mathrm{mg} / \mathrm{dl})$ & & & \\
\hline & $\operatorname{IgA}(\mathrm{mg} / \mathrm{dl})$ & -0.197 & 0.256 & Non-significant \\
\hline \multirow{2}{*}{$\operatorname{IgG}(\mathrm{mg} / \mathrm{dl})$} & $\operatorname{IgM}(\mathrm{mg} / \mathrm{dl})$ & -0.092 & 0.599 & Non-significant \\
\hline & $\operatorname{IgA}(\mathrm{mg} / \mathrm{dl})$ & 0.046 & 0.792 & Non-significant \\
\hline \multirow{2}{*}{$\operatorname{IgA}(\mathrm{mg} / \mathrm{dl})$} & $\operatorname{IgM}(\mathrm{mg} / \mathrm{dl})$ & -0.197 & 0.256 & Non-significant \\
\hline & $\mathrm{IgG}(\mathrm{mg} / \mathrm{dl})$ & 0.046 & 0.792 & Non-significant \\
\hline \multicolumn{2}{|c|}{ Salivary Igs levels in Non-Smokers } & $\mathrm{r}$ & $\mathrm{p}$ & Significance \\
\hline
\end{tabular}


Cont... Table.4: Correlation between Salivary Igs levels (IgM, IgG and IgA) in the Study Samples.

\begin{tabular}{|l|l|l|l|l|}
\hline \multirow{2}{*}{$\operatorname{IgM}(\mathrm{mg} / \mathrm{dl})$} & $\operatorname{IgG}(\mathrm{mg} / \mathrm{dl})$ & 0.124 & 0.478 & Non-significant \\
\cline { 2 - 5 } & $\operatorname{IgA}(\mathrm{mg} / \mathrm{dl})$ & -0.43 & 0.807 & Non-significant \\
\hline \multirow{2}{*}{$\operatorname{IgG}(\mathrm{mg} / \mathrm{dl})$} & $\operatorname{IgM}(\mathrm{mg} / \mathrm{dl})$ & 0.124 & 0.478 & Non-significant \\
\cline { 2 - 5 } & $\operatorname{IgA}(\mathrm{mg} / \mathrm{dl})$ & 0.08 & 0.649 & Non-significant \\
\hline \multirow{2}{*}{$\operatorname{IgA}(\mathrm{mg} / \mathrm{dl})$} & $\operatorname{IgM}(\mathrm{mg} / \mathrm{dl})$ & -0.43 & 0.807 & Non-significant \\
\cline { 2 - 5 } & $\operatorname{IgG}(\mathrm{mg} / \mathrm{dl})$ & 0.08 & 0.649 & Non-significant \\
\hline
\end{tabular}

According to the BMI and SI in smokers, no significant differences were found in both serum and salivary Igs levels.

\section{Discussion}

Alteration in the immunological functions for both antibody and cell mediated immunity might be due to the inhalation of tobacco smoke ${ }^{(12,13)}$.Several previous studies in other countries authorized that serum levels of Igs were lower in smokers by $10-20 \%$ as compared with non-smokers individuals ${ }^{(14)}$.Depending on the results of the current study, non-significant increase in terms of serum IgM was found in smokers which came in agreement with the results of Arinola et al. ${ }^{(15)}$ and Gonzalez-Quintela et al. ${ }^{(16)}$ who stated that this increased may be attributable to the ability of $\operatorname{IgM}$ in neutralizing the harmful toxins found in tobacco smoke by complement activation, conversely, Tarbiah et al. ${ }^{(13)}$ reported a significant increased while Olayanju et al. ${ }^{(17)}$ reported a significant decreased in the serum $\operatorname{IgM}$ in smokers as compared with non-smokers. In addition results of this research showed that both serum $\operatorname{IgG}$ and IgA levels were decreased significantly in smokers which were similar to the findings of Tarbiah et al. (13) in terms of IgG and Aula and Fikry ${ }^{(18)}$ in terms of IgA level, however, IgG and IgA levels were found to be higher in smokers according to Prajapati and Jyoti study ${ }^{(19)}$.Various investigations have concentrated on the possible mechanisms by which tobacco smoke might alter B-cells (which responsible for the production of Igs after their differentiation into plasma cells) development, functioning and distribution, it was found that tobacco smoke might cause down regulation of murine marrow B220+CD34- pre-B cells and/or B220+CD34+ pro-B cells which they effect on B-cells development ${ }^{(20)}$. In addition several molecular studies have stated that nicotinic receptors such as $\alpha 4$ and $\alpha 7$ subunits which have essential roles in B-cells lines show elevated expression after long term exposure to nicotine which suppress B-cells secretions ${ }^{(21)}$. Furthermore, it was found that proliferative ability of T-cells and T-cells dependent antibody responses were decreased in smokers which subsequently suppress B-cells functions and causes reduction in the production of serum $\operatorname{Igs}^{(22)}$.Moreover low number and impaired functions of regulatory B-cells in smokers infected by Helicobacter pylori had been improved by Li et al. ${ }^{(23)}$.It was found that after smoking cessation the levels of serum IgM and IgG were increased significantly, however the level of $\operatorname{IgA}$ remained the same ${ }^{(24)}$.Despite the fact that blood considered as an essential sample for disease diagnosis; saliva reveals the mucosal and systemic expression of many biomarkers in the human body, salivary IgA initiate from the plasma cells found in salivary glands, while salivary IgM and $\mathrm{IgG}$ are mainly originate from the serum ${ }^{(25)}$. Regarding the results of the present study, salivary IgM revealed non-significant increase in smokers which analogs with the results of Barton et al. ${ }^{(26)}$ but a significant decreased in salivary IgG and IgA which came in agreement with the results of Giuca et al. ${ }^{(27)}$.It has been demonstrated that tobacco smoke has an adverse effect on the oral mucosa by altering the amounts of saliva secretions, enzymes and immune functions ${ }^{(28)}$, so the reduction of salivary Igs which have important roles in mucosal defenses may increase the susceptibility of the smokers to develop several oral infections such as chronic periodontitis ${ }^{(29)}$. Low level of salivary IgA which was found in this paper may be due to the perceived impact of tobacco smoke on the salivary glands or on other immunological cells that responsible for the production of salivary IgA. The absence of positive correlation in the smokers Igs levels in both serum and saliva in this study may be due to the smaller size of the smoking samples, in addition this study included only men because of the low prevalence 
of smoking in females.

\section{Conclusions}

According to the data of the current study, tobacco smoking is strongly associated with the suppression of B-cell functions and thus alters the Igs production and levels in both serum and saliva samples of smokers individuals.

Ethical Clearance: The Research Ethical Committee at scientific research by ethical approval of both MOH and MOHSER in Iraq

\section{Conflict of Interest: Non}

Funding: Self-funding

\section{References}

1. Xiao D, Wang C. Rising smoking epidemic among adolescents in China. The Lancet Respiratory Medicine. 2019;7(1):3-5.

2. Mainali P, Pant S, Rodriguez AP, Deshmukh A, Mehta JL. Tobacco and cardiovascular health. Cardiovascular toxicology. 2015;15(2):107-16.

3. Organization WHO. WHO report on the global tobacco epidemic 2015: raising taxes on tobacco: World Health Organization; 2015.

4. Hussain Z, Sullivan R. Tobacco in post-conflict settings: the case of Iraq. ecancermedicalscience. 2017;11.

5. Friedrichs B, Neumann U, Schüller J, Peck MJ. Cigarette-smoke-induced priming of neutrophils from smokers and non-smokers for increased oxidative burst response is mediated by TNF- $\alpha$. Toxicology in Vitro. 2014;28(7):1249-58.

6. Perricone C, Versini M, Ben-Ami D, Gertel S, Watad A, Segel MJ, et al. Smoke and autoimmunity: The fire behind the disease. Autoimmunity reviews. 2016;15(4):354-74.

7. Shilpashree H, Sarapur S. Evaluation of salivary immunoglobulin A levels in tobacco smokers and patients with recurrent aphthous ulcers. Journal of natural science, biology, and medicine. 2012;3(2):177.

8. Vaillant AAJ, Ramphul K. Immunoglobulin. StatPearls [Internet]: StatPearls Publishing; 2019.

9. Tariq SF, Hussein TA. Study of the Immunological Status of Iraqi Vitiligo Patients. Baghdad Science Journal. 2016;13(3):454-62.
10. Brandtzaeg P. Secretory immunity with special reference to the oral cavity. Journal of oral microbiology. 2013;5(1):20401.

11. Wagner III WE. Using IBM $®$ SPSS $®$ statistics for research methods and social science statistics: Sage Publications; 2019.

12. Qiu F, Liang C-L, Liu H, Zeng Y-Q, Hou S, Huang $\mathrm{S}$, et al. Impacts of cigarette smoking on immune responsiveness: Up and down or upside down? Oncotarget. 2017;8(1):268.

13. Tarbiah N, Todd I, Tighe PJ, Fairclough LC. Cigarette smoking differentially affects immunoglobulin class levels in serum and saliva: An investigation and review. Basic \& Clinical Pharmacology \& Toxicology. 2019;125(5):474-83.

14. Al-Ghamdi HS, Anil S. Serum antibody levels in smoker and non-smoker Saudi subjects with chronic periodontitis. Journal of periodontology. 2007;78(6):1043-50.

15. Arinola $\mathrm{O}$, Akinosun $\mathrm{O}$, Olaniyi J. Passive-and active-cigarette smoking: Effects on the levels of antioxidant vitamins, immunoglobulin classes and acute phase reactants. African Journal of Biotechnology. 2011;10(32):6130-2.

16. Gonzalez-Quintela A, Alende R, Gude F, Campos J, Rey J, Meijide L, et al. Serum levels of immunoglobulins (IgG, IgA, IgM) in a general adult population and their relationship with alcohol consumption, smoking and common metabolic abnormalities. Clinical \& Experimental Immunology. 2008;151(1):42-50.

17. Olayanju AO, Rahamon SK, Arinola OG. Salivary immunoglobulin classes in Nigerian cigarette smokers: Indication for increased risk of oral diseases. Dental research journal. 2012;9(5):531.

18. Aula FA, Qadir FA. Effects of cigarette smoking on some immunological and hematological parameters in male smokers in Erbil city. Jordan Journal of Biological Sciences. 2013;147(624):1-8.

19. Prajapati KJ, Chawda JG. Estimation of major immunoglobulins in smokers and gutkha chewers. Journal of oral and maxillofacial pathology: JOMFP. 2016;20(2):219.

20. Palmer VL, Kassmeier MD, Willcockson J, Akhter MP, Cullen DM, Swanson PC. N-acetylcysteine increases the frequency of bone marrow pro-B/ pre-B cells, but does not reverse cigarette smokinginduced loss of this subset. PloS one. 2011;6(9). 
21. Brandsma C-A, Kerstjens HA, van Geffen WH, Geerlings M, Postma DS, Hylkema MN, et al. Differential switching to IgG and IgA in active smoking COPD patients and healthy controls. European Respiratory Journal. 2012;40(2):313-21.

22. Tejero JD, Armand NC, Finn CM, Dhume K, Strutt TM, Chai KX, et al. Cigarette smoke extract acts directly on CD4 $\mathrm{T}$ cells to enhance Th1 polarization and reduce memory potential. Cellular immunology. 2018;331:121-9.

23. Li G, Wulan H, Song Z, Paik PA, Tsao ML, Goodman GM, et al. Regulatory B cell function is suppressed by smoking and obesity in H. pyloriinfected subjects and is correlated with elevated risk of gastric cancer. PLoS One. 2015;10(7).

24. Mili F, Flanders WD, Boring JR, Annest JL, Destefano F. The associations of race, cigarette smoking, and smoking cessation to measures of the immune system in middle-aged men. Clinical immunology and immunopathology. 1991;59(2):187-200.

25. Oba MK, de-Macedo LD, Motta ACF, Ricz HMA,
de-Freitas LCC, Saggioro FP, et al. Mucosaassociated lymphoid tissue lymphoma in labial minor salivary glands-case report and literature review. Journal of Oral Diagnosis. 2019;4(1):1-5.

26. Barton J, Riad M, Gaze M, Maran A, Ferguson A. Mucosal immunodeficiency in smokers, and in patients with epithelial head and neck tumours. Gut. 1990;31(4):378-82.

27. Giuca MR, Pasini M, Tecco S, Giuca G, Marzo G. Levels of salivary immunoglobulins and periodontal evaluation in smoking patients. BMC immunology. 2014;15(1):5.

28. Al-Zyoud W, Hajjo R, Abu-Siniyeh A, Hajjaj S. Salivary Microbiome and Cigarette Smoking: A First of Its Kind Investigation in Jordan. International Journal of Environmental Research and Public Health. 2020;17(1):256.

29. Pietiäinen M, Liljestrand JM, Akhi R, Buhlin $\mathrm{K}$, Johansson A, Paju S, et al. Saliva and serum immune responses in apical periodontitis. Journal of clinical medicine. 2019;8(6):889. 